\title{
Article \\ Comparative Analysis Reveals Changes in Some Seed Properties in Amaranth Mutant Variety 'Zobor' (A. hypochondriacus $\times$ A. hybridus)
}

\author{
Andrea Hricová ${ }^{1,+}$, Veronika Mistríková ${ }^{1,+}\left(\mathbb{D}\right.$, Alena Gajdošová ${ }^{1}$, Jozef Fejér ${ }^{2}$ (D) Jana Nôžková ${ }^{3}$, \\ Susanna Kariluoto ${ }^{4}$ (D) Ján Gažo ${ }^{3}$ and Monika Szabóová ${ }^{1, * \mathbb{D}}$
}

check for updates

Citation: Hricová, A.; Mistríková, V.; Gajdošová, A.; Fejér, J.; Nôžková, J.; Kariluoto, S.; Gažo, J.; Szabóová, M. Comparative Analysis Reveals

Changes in Some Seed Properties in Amaranth Mutant Variety 'Zobor' ( $A$ hypochondriacus $\times$ A. hybridus). Agronomy 2021, 11, 2565. https:// doi.org/10.3390/agronomy11122565

Academic Editor: Aurora Díaz Bermúdez

Received: 16 November 2021

Accepted: 15 December 2021

Published: 16 December 202

Publisher's Note: MDPI stays neutra with regard to jurisdictional claims in published maps and institutional affiliations.

Copyright: (C) 2021 by the authors Licensee MDPI, Basel, Switzerland This article is an open access article distributed under the terms and conditions of the Creative Commons Attribution (CC BY) license (https:// creativecommons.org/licenses/by/ $4.0 /)$
1 Institute of Plant Genetics and Biotechnology, Plant Science and Biodiversity Center, Slovak Academy of Sciences, 95007 Nitra, Slovakia; andrea.hricova@savba.sk (A.H.); veronika.mistrikova@savba.sk (V.M.); alena.gajdosova@savba.sk (A.G.)

2 Department of Ecology, Faculty of Humanities and Natural Sciences, University of Prešov, 08001 Prešov, Slovakia; jozef.fejer@unipo.sk

3 Institute of Plant and Environmental Sciences, Faculty of Agrobiology and Food Resources, Slovak University of Agriculture, 94976 Nitra, Slovakia; janka.nozkova@uniag.sk (J.N.); jan.gazo@uniag.sk (J.G.)

4 Department of Food and Nutrition, University of Helsinki, 00100 Helsinki, Finland; susanna.kariluoto@helsinki.fi

* Correspondence: m.szaboova@savba.sk

+ These authors contributed equally to this work.

Abstract: The aim of our long-term research program is to improve the quality and quantity of amaranth production through mutation breeding using $\gamma$-radiation. In this paper, we present the characterization of the new variety 'Zobor' of A. hypochondriacus $\times$ A. hybridus developed by radiationinduced mutagenesis of hybrid K-433. Multiyear phenotypic characterization of an important yield parameter (1000-seed weight) showed that the studied mutant variety 'Zobor' has an advantage in seed weight over the nonirradiated control seeds of K-433 with predictable performance of this yield trait. 'Zobor' exhibited changes in seed morphometric parameters, starch particle size, and pasting properties with no change in amylose content and swelling power. Moreover, the seeds of 'Zobor' showed the significantly highest folate content among selected amaranth varieties. The mutant variety could, therefore, be interesting for the development of functional foods and as a low-management crop, attractive for cultivation in Europe.

Keywords: amaranth; mutation; quality; nutrition; seed; starch; folate

\section{Introduction}

Amaranthus is a cosmopolitan genus of annual and perennial plants characterized by high stress tolerance, environmental adaptability, and ability to grow with minimal external inputs. The genus includes domesticated and endangered species, restricted endemics, and widespread weeds [1]. Amaranthus has more than 80 species [2], which are distributed in many parts of the world and can be grouped as grain (pseudocereals), vegetable, ornamental, and weed types [3]. Within the genus Amaranthus, there is a high genetic variation as a result of outcrossing ranging from $5 \%$ to $30 \%$ and plant hybridization, which promotes gene exchange. The ability of interspecific hybridization between the weedy and cultivated types, with the first acting as the "reservoir" of unique genes, as well as gene exchange, has increased crop adaptability to adverse environmental conditions [4].

Amaranthus spp. as underutilized species have promising economic and nutritional value. They are valuable plants with a high content of essential nutrients and potential health benefits for consumers, as well as usability for the preparation of healthy food and food additives, vegetables, beverages, animal feed, pharmaceutical products, and industrial nonfood production of byproducts. Many of the amaranth species are medicinally important and possess antiallergic, anticancer, antihypertensive, and antioxidant properties; they 
can be used as cereals, dye plants, feed, medicinal plants, ornamentals, and vegetables. Domesticated amaranth species are known for their attractive chemical composition and nutritional potential compared to cereals or legumes with a high impact on human health. Amaranth leaves and seeds are known to be rich in micronutrients and vitamins, especially chlorine, copper, iron, manganese, sodium, calcium, vitamin A, vitamin C, and B group vitamins. Amaranth seeds have a high protein content with an excellent amino-acid profile and are an important (alternative) source of protein in the celiac, vegetarian, or vegan diet. The seeds are a good source of unsaturated fatty acids such as palmitic, oleic, linoleic, and linolenic acids and a rich source of squalene and tocotrienols, which play an important role in lowering LDL-cholesterol in the blood and, thus, may act as protective factors against heart attacks. In addition, amaranth seeds contain high levels of starch and can be considered a good source of folate [1,5-8].

Folate is a generic term for both naturally occurring dietary folate and folic acid (not found in foods), the fully oxidized monoglutamate vitamer used in dietary supplements and fortified foods. Folate is required for numerous body functions. In conjunction with vitamins B12 and B6, folate plays an essential role in nucleotide synthesis, methionine regeneration in DNA methylation, and oxidation and reduction of one-carbon units required for normal metabolism and regulation [9]. Folate deficiency causes severe abnormalities in one-carbon metabolism, leading to DNA hypomethylation, which causes certain types of chronic diseases and developmental disorders during embryogenesis [10]. According to Krawinkel et al. [11], the recommended daily intake of folate is 300-400 $\mu \mathrm{g}$.

Considering global climate change and its potential negative impact on agriculture systems, amaranth can contribute to global food security as a highly adaptable and nutrientrich crop [1,5]. Amaranth is still rarely grown in Europe. To compete economically with other grain crops, amaranth requires satisfactory and stable grain yields and a high-quality grain composition. These objectives can be achieved partly by optimal crop management and partly by selection and breeding [12]. Breeding objectives are high-yielding, short, early, and uniform maturing lines with reduced seed shattering to improve harvestability and large seeds with high nutritional value [13,14]. Although plant hybridization is a common approach used in many important feed and food crops, grain amaranths (predominantly A. cruentus L., A. hypochondriacus, and A. caudatus) have not yet been subjected to intense breeding. In many crops, hybrid varieties are characterized by increased vigor and yield. In Amaranthus breeding, the application of hybridization is also very promising, because a mid-parent heterosis of up to $88 \%$ has been reported [15]. In the report of Stetter et al. [16], some approaches for hybrid production were described, but the authors emphasized that the key step in all methods is to prevent self-fertilization by the male parent to some extent.

Breeding of new cultivars with improved traits through conventional breeding methods, advanced molecular breeding, or gene introgression is strongly recommended to reduce the impact of climate change on global food security $[13,17,18]$. In addition to classical breeding and biotechnological approaches, genetic improvement of amaranth has also been attempted through radiation-induced mutagenesis. This approach has the potential to induce small genetic changes that can significantly affect critical agronomic traits [19-23]. Moreover, mutation breeding is a simple and cost-effective technology [24,25].

Guidelines for the application of mutation breeding in amaranth and quinoa can be found in the paper of Gomez-Pando [26]. The authors focused on the selection and origin of initial plant material. The initial material selected for mutagenic treatments must be suitable for the objectives. Preferably, it must have good adaptability and yield potential, and the degree of phenotypic variability in the parent cultivars should be determined before seed treatment. Data on amaranth trait evaluation and characterization were summarized in the review of Grobelnik Mlakar et al. [27]. The authors described the taxonomic classification of amaranth, as well as its morphology, nutritional value, use, and importance as a perspective crop in temperate climates.

The amaranth seed size, as one of the morphometric parameters, is generally not the topic of interest [28], although seed morphology has been described in detail by 
several authors [29-31]. Pseudocereal grains show different external and internal seed architecture with consequent differences in nutrient distribution [30]. This characterization can, therefore, reveal different and specific microvariations (in seed architecture, shape, color, and weight) within the Amaranthus genus and may be helpful for breeders to select suitable cultivars.

The aim of the study presented here was to analyze some seed properties of the amaranth mutant variety 'Zobor', which was developed by radiation-induced mutagenesis of the hybrid K-433 (A. hypochondriacus $\times$ A. hybridus). Phenotypic characterization, evaluation of seed morphological and morphometric traits, and evaluation of an important yield parameter, 1000-seed weight, were carried out. To determine the nutritional potential of the mutant variety, analyses of starch, some starch traits, and folate content were performed. The experiments were conducted over four growing seasons, and the data obtained for the mutant variety 'Zobor' were compared with the original nonirradiated hybrid K-433 and the other grain genotype Ficha (A. cruentus).

\section{Materials and Methods}

\subsection{Plant Material, Phenotypic Traits, and 1000-Seed Weight}

Two species of amaranth were studied in the present investigation: Amarantus cruentus L.- -genotype Ficha and Amaranthus hypochondriacus $\times$ Amaranthus hybridus-accession K-433 and variety 'Zobor'. The Slovak mutant variety 'Zobor' was bred at the Institute of Plant Genetics and Biotechnology by radiation mutagenesis [19]. 'Zobor' was registered as a new variety with a long-term significantly increased 1000-seed weight over the nonirradiated control hybrid K-433 after DUS test examination. DUS testing is a method of determining whether a newly bred variety is clearly distinguishable from other existing varieties within the same species (distinctness), whether the individual plants of the new variety are uniform at the same stage of propagation (uniformity), and whether these characteristics do not change during subsequent generations (stability). The tests were conducted according to the International Union for the Protection of New Varieties of Plants (UPOV) Guidelines [32] over a standard period of 2 years (2014-2016) in an approved center, the Central Control and Testing Institute for Agriculture in Nové Zámky, Slovakia (122 m above sea level; $47^{\circ} 59^{\prime} 9.841^{\prime \prime} \mathrm{N} 18^{\circ} 9^{\prime} 50.634^{\prime \prime} \mathrm{E}$ ). 'Zobor' as a candidate for a new variety was compared to a similar variety from the reference collection Koniz (Amaranthus hypochondriacus $\times$ Amaranthus hybridus).

The field experiments in the present study were conducted at the locality Nitra $(290 \mathrm{~m}$ above sea level; $48^{\circ} 18^{\prime} 53.442^{\prime \prime} \mathrm{N} 18^{\circ} 5^{\prime} 16.75^{\prime \prime}$ E). The soil type in Nitra is a Haplic Luvisol with $\mathrm{pH}$ of 7.4. The experiment was designed as a block in a split-plot arrangement with four replicates, and the plot size was $2.0 \mathrm{~m} \times 1.5 \mathrm{~m}\left(2.5 \mathrm{~m}^{2}\right)$ for each experimental variant. Isolation was provided by a $1 \mathrm{~m}$ wide maize plot between each amaranth sample. No fertilizers or sprays were used during the growing season. Seeds were sown in May, and plants were harvested by hand in October each year. The panicles were cut and dried naturally, and the seeds were harvested by hand. Plants were cultivated during four consecutive years (2008-2011 as Y1-Y4, Figure S1).

The weight of 1000 seeds was calculated as the average of 10 independent measurements for each amaranth sample.

\subsection{Morphological and Morphometric Analysis of the Seeds}

For morphological analysis, amaranth seeds were prefixed in $4 \%(w / v)$ formaldehyde in $0.1 \mathrm{M}$ potassium phosphate buffer ( $\mathrm{pH} 7.0$ ) for $2 \mathrm{~h}$ by vacuum filtration at room temperature. The fixative solution was then replaced with a new one, and seeds were fixed at $4{ }^{\circ} \mathrm{C}$ for an additional $24 \mathrm{~h}$. The seeds were then washed (three times in $0.1 \mathrm{M}$ potassium phosphate buffer). After washing, the seeds were dehydrated in a graded ethanol series $(30 \%$, $50 \%, 70 \%, 80 \%, 90 \%, 96 \%$, and $100 \%$ ethanol). Ethanol was gradually replaced with xylene $(3: 1,1: 1,1: 3 \mathrm{v} / \mathrm{v})$ up to $100 \%$ xylene and xylene/paraplast plus resin mixtures $(3: 1,1: 1,1: 3$ $v / v$ ). Seeds were finally embedded in resin at $60^{\circ} \mathrm{C}$ for $48 \mathrm{~h}$. The $10 \mu \mathrm{m}$ thick semithin 
sections were cut using a MicroTec Cut 4055 rotary microtome (Walldorf, Germany) and placed on glass slides treated with egg white glycerol adhesive. The sections were deparaffinized, hydrated, and stained with $0.25 \%(w / v)$ toluidine blue $\mathrm{O}$ in aqueous solution for a few seconds and mounted with Entellan ${ }^{\mathrm{TM}}$. The stained sections were observed with an Axioplan 2 light microscope (Carl Zeiss, Oberkochen, Germany), photographed with a Sony DXC-S500 digital color camera system, and analyzed with ImageJ software [33].

For morphometric analysis, 50 dried, undamaged seeds (Y4) typical of the genotype were randomly selected. Images of the selected seeds were acquired using a ZEISS Stereo Discovery V20 stereo microscope (Carl Zeiss, Oberkochen, Germany) equipped with a MRc5 camera. Seeds were placed on a dark carbon tape to prevent displacement, always in the same orientation. The dorsal side of the seed was imaged in a horizontal view, and the ventral side of the seed was imaged in a vertical view. The acquired images were then processed using ZEISS Axiovision software version 4.8 (Carl Zeiss, Oberkochen, Germany). Seeds were automatically segmented and then measured by the software. The following parameters were selected: area $\left(\mathrm{mm}^{2}\right)$, bound width $(\mathrm{mm})$, bound height $(\mathrm{mm})$, perimeter $(\mathrm{mm})$, diameter $(\mathrm{mm})$, and radius $(\mathrm{mm})$ (Table S1; Figures 1-3). The collected data were statistically analyzed using SAS ${ }^{\circledR}$ (Cary, NC, USA) Enterprise Guide 5.1 software.

\subsection{Starch Isolation and Analysis}

Amaranth starch was extracted following the acid procedure of Calzetta Resio et al. [34] with some modifications. Amaranth seeds of $0.1 \mathrm{~g}$ were soaked for $1.5 \mathrm{~h}$ in a solution with $\mathrm{SO}_{2}$ concentration of $0.041 \%(w / v)$ at $53.9^{\circ} \mathrm{C}$. They were surface-dried for $20 \mathrm{~min}$ at the same temperature. All samples were homogenized with mortar and pestle and transferred to a microcentrifuge tube. For each $0.1 \mathrm{~g}$ of flour, $0.001 \mathrm{~g}$ of acarbose, $5 \mu \mathrm{L}$ of acid protease, $5 \mu \mathrm{L}$ of viscozyme, and $1 \mathrm{~mL}$ of acetate buffer $(\mathrm{pH} 5.0)$ were added. The samples were incubated overnight at $37^{\circ} \mathrm{C}$ on a shaker. The suspension was centrifuged at $13,000 \times g$ for $5 \mathrm{~min}$, the supernatant was discarded, and the pellet was resuspended in $1.0 \mathrm{~mL}$ of $2 \%$ SDS and centrifuged at $13,000 \times g$ for $5 \mathrm{~min}$. The pellet was resuspended in $1.0 \mathrm{~mL}$ of $50 \%(w / v$, density $1.6 \mathrm{~g} / \mathrm{mL})$ aqueous $\mathrm{CsCl}$ and centrifuged at $13,000 \times \mathrm{g}$ for $5 \mathrm{~min}$. The top layer was mechanically disrupted and centrifuged for $10 \mathrm{~min}$. The supernatant was discarded, and the pellet was resuspended in $1.0 \mathrm{~mL}$ of fresh aqueous $\mathrm{CsCl}$ at $13,000 \times g$ for $10 \mathrm{~min}$. For further purification, the pellet was washed twice with distilled water and twice with ethanol at $13,000 \times g$ for $10 \mathrm{~min}$. The purified starch was dried overnight at room temperature.
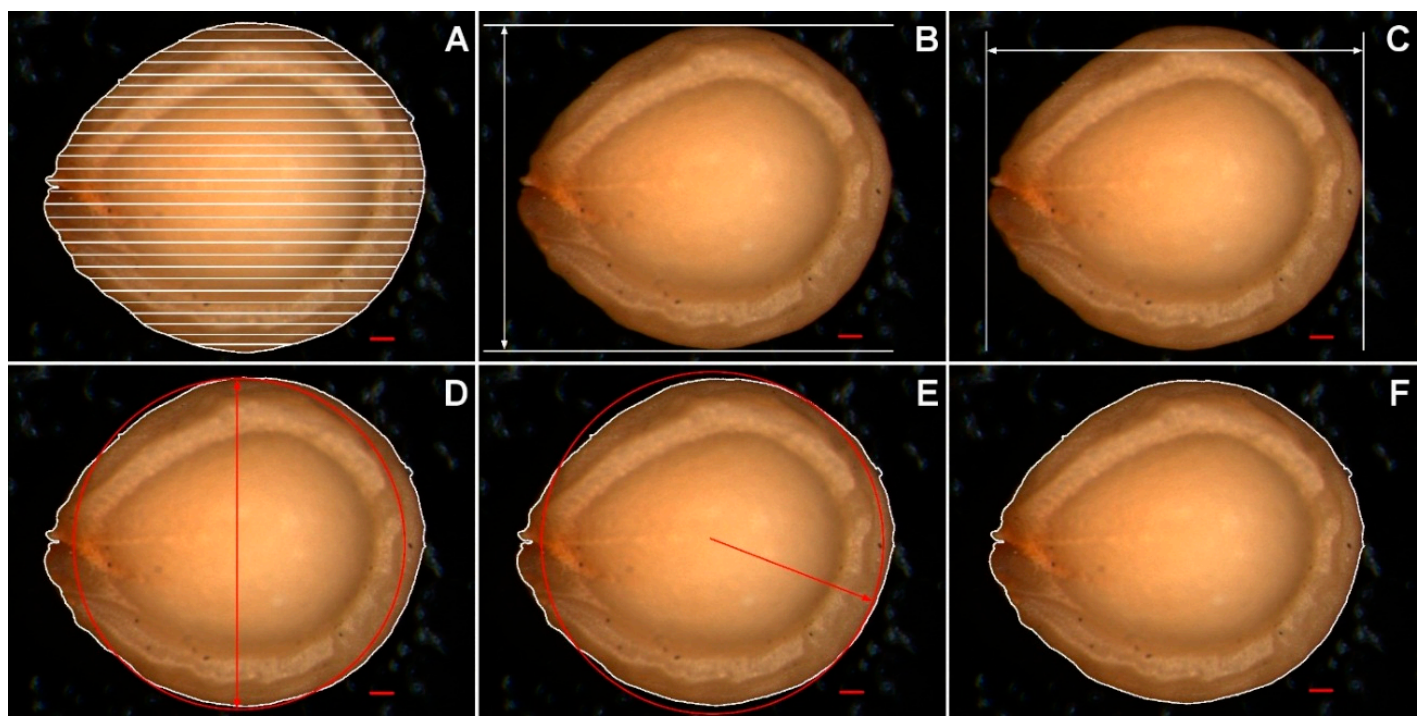

Figure 1. Schematic representation of the measured morphometric parameters on dorsal side of amaranth seed: (A) area $\left(\mathrm{mm}^{2}\right) ;(\mathbf{B})$ bound height $(\mathrm{mm}) ;(\mathbf{C})$ bound width $(\mathrm{mm}) ;(\mathbf{D})$ diameter $(\mathrm{mm}) ;(\mathbf{E})$ radius $(\mathrm{mm}) ;(\mathbf{F})$ perimeter $(\mathrm{mm})$. Scale bar: $100 \mu \mathrm{m}$. 

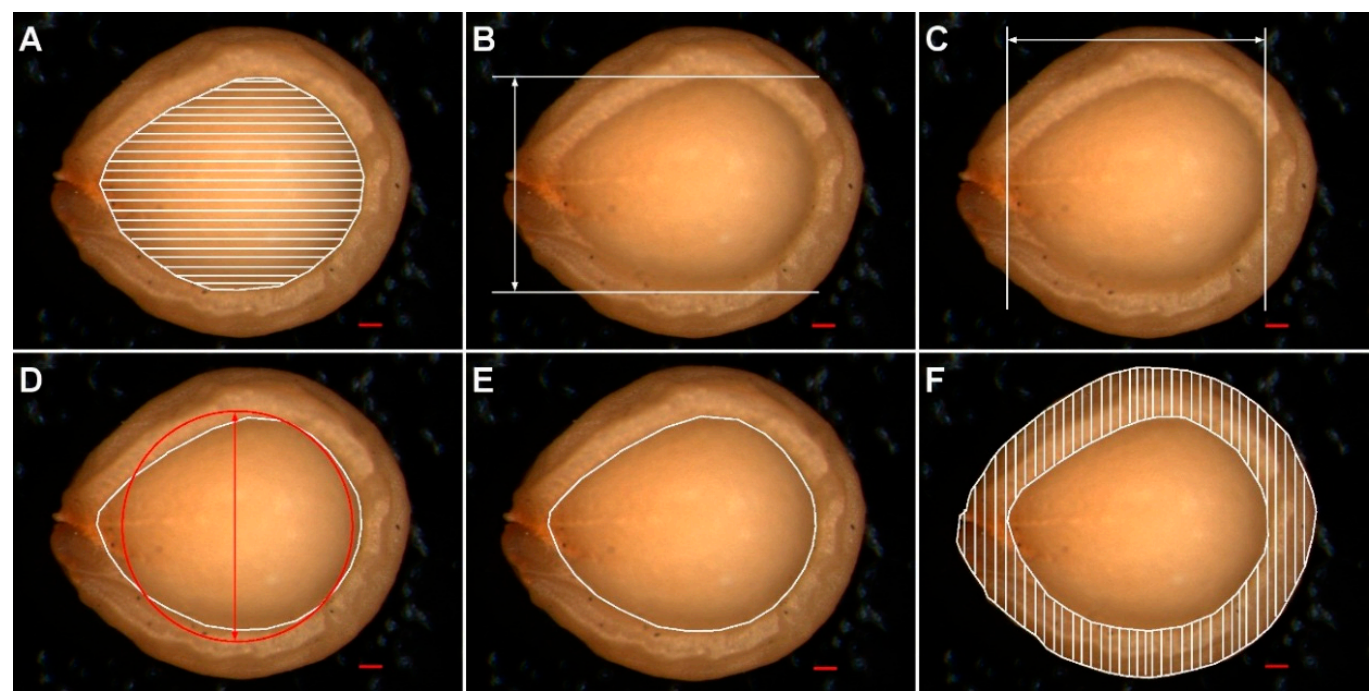

Figure 2. Schematic representation of the measured morphometric parameters of perisperm (A-E) and pericarp (F) on dorsal side of amaranth seed: $(\mathbf{A})$ area $\left(\mathrm{mm}^{2}\right) ;(\mathbf{B})$ bound height $(\mathrm{mm}) ;(\mathbf{C})$ bound width $(\mathrm{mm}) ;(\mathbf{D})$ diameter $(\mathrm{mm})$; (E) perimeter $(\mathrm{mm}) ;(\mathbf{F})$ area $\left(\mathrm{mm}^{2}\right)$. Scale bar: $100 \mu \mathrm{m}$.

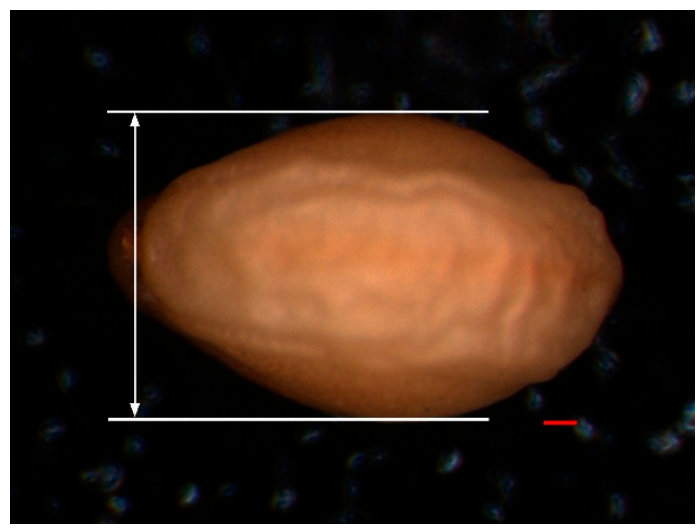

Figure 3. Schematic representation of the measured morphometric parameter on ventral side of amaranth seed: bound height (mm). Scale bar: $100 \mu \mathrm{m}$.

The determination of amylose was performed according to the method of Mohammadkhani et al. [35]. Five milligrams of extracted starch including standard maize samples (27\% amylose content and 100\% maize amylopectin) were used. For each $1 \mathrm{mg}$ of starch, $15 \mu \mathrm{L}$ of $95 \%$ ethanol and $90 \mu \mathrm{L}$ of $1 \mathrm{M}$ aqueous $\mathrm{NaOH}$ were added. The samples were mixed well and shaken overnight at room temperature. The samples were diluted with distilled water to give $1 \mathrm{mg}$ of starch per $200 \mu \mathrm{L}$. Subsamples of $200 \mu \mathrm{L}$ of each starch solution were taken, neutralized with $1 \mathrm{~mL}$ of $0.05 \mathrm{M}$ aqueous citric acid, stained with $800 \mu \mathrm{L}$ of iodine solution, and diluted with $10 \mathrm{~mL}$ of distilled water to a final volume of $12 \mathrm{~mL}$. The solutions were cooled to $18^{\circ} \mathrm{C}$ for $20 \mathrm{~min}$. The preparation of each sample was repeated four times, and absorbance was measured at $620 \mathrm{~nm}$ and $535 \mathrm{~nm}$. The readings were converted to amylose contents in three ways. First, only the $620 \mathrm{~nm}$ absorbance curve was used. The absorbance values at $620 \mathrm{~nm}$ and $535 \mathrm{~nm}$ were evaluated according to ratio-based calculations. These calculations are intended to evaluate both the amylopectin content and the amylose content, thus compensating to some extent for the variations in the total starch content of the sample.

$$
\text { Amylose }(\%)=\frac{\mathrm{AP}_{620}-\mathrm{AP}_{535} * \mathrm{R}}{\left(\left(\mathrm{AM}_{535}-\mathrm{AP}_{535}\right) * \mathrm{R}\right)-\left(\mathrm{AM}_{620}-\mathrm{AP}_{620}\right)}
$$


where $R$ is the ratio of absorbance at $620 \mathrm{~nm}$ to absorbance at $535 \mathrm{~nm}, \mathrm{AP}_{535}$ is the slope of the absorbance curve of amylopectin at $535 \mathrm{~nm}, \mathrm{AM}_{535}$ is the slope of the absorbance curve of amylose at $535 \mathrm{~nm}$, and $\mathrm{AP}_{620}$ is the slope of the absorbance curve of amylose at $620 \mathrm{~nm}$ [36].

The swelling test was developed from the swelling power test and the swelling volume test [37]. The analysis was performed in triplicate per sample. The samples (flour of $40 \mathrm{mg}$ DW) were mixed with water and kept in a water bath at $92.5^{\circ} \mathrm{C}$ for $30 \mathrm{~min}$ with regular gentle swirling $(1 \mathrm{~min} 20 \times ; 1.5 \mathrm{~min} 2 \times ; 2 \min 2 \times ; 3 \mathrm{~min} 2 \times ; 4 \mathrm{~min} 2 \times ; 5 \min 2 \times ; 7.5 \mathrm{~min}$ $2 \times ; 10 \min 2 \times ; 15 \min 2 \times ; 25 \min 2 \times$ ). The samples were cooled to room temperature in a water bath $\left(20^{\circ} \mathrm{C}\right)$ for $3 \mathrm{~min}$, being gently inverted twice at the beginning and after $1.5 \mathrm{~min}$. Samples were then centrifuged at $16,000 \times g$ for $10 \mathrm{~min}$, and total starch swelling power was calculated as the ratio between the weight of the residue and the DW of the flour.

Particle size analysis was performed in a Coulter LS 230 (Beckman Coulter, Brea, CA, USA) using the entire starch sample in the flow through small-sample volume sampler, optimized for the refractive index of starch in water. The results are represented as weighted mean size and were calculated as particles with a diameter between 0.3 and $3 \mu \mathrm{m}$. The analyses of amylose, swelling test, and starch particle size were performed over four growing seasons (Y1-Y4).

Pasting properties of starch were determined using a Rapid Visco Analyzer (RVA, Model 3D, Newport Scientific, Warriewood, NSW, Australia), as described by Konik et al. [38], using Thermocline software for Windows. A flour sample of $3.5 \mathrm{~g}$ (14\% moisture basis) was weighted into a canister filled with $25 \mathrm{~mL}$ of deionized water. The process started at $50{ }^{\circ} \mathrm{C}$ for $1 \mathrm{~min}$, followed by a linear increase in temperature to $95^{\circ} \mathrm{C}$ in $3 \mathrm{~min} 42 \mathrm{~s}$, holding at $95^{\circ} \mathrm{C}$ for $2 \mathrm{~min} 30 \mathrm{~s}$, then cooling the system to $50^{\circ} \mathrm{C}$ in $3 \mathrm{~min} 48 \mathrm{~s}$, holding at $50{ }^{\circ} \mathrm{C}$, and terminating the process after 13 min according to AACC method 76-21.02 [39]. The results were reported as temperature of pasting (PT), peak viscosity, viscosity at $95{ }^{\circ} \mathrm{C}$ holding (hold), viscosity at $50{ }^{\circ} \mathrm{C}$ (final), breakdown, and setback. The samples were measured in duplicate. The pasting properties of starch were made in duplicate from one growing season (Y4).

\subsection{Folate}

For folate analysis, $0.5 \mathrm{~g}$ of sample was weighed and extracted with $15 \mathrm{~mL}$ of extraction buffer (50 mM CHES/50 mM HEPES, 10 mM 2-mercaptoethanol, 2\% sodium ascorbate; $\mathrm{pH}$ 7.85) in boiling water for $10 \mathrm{~min}$, followed by a tri-enzyme treatment with $\alpha$-amylase, hog kidney conjugase, and protease [40]. A blank sample was analyzed for each set of samples.

Total folate assay was carried out in 96-well microtiter plates using glycerol-cryoprotected Lactobacillus rhamnosus (ATCC 7469) as the growth organism and 5-formyltetrahydrofolate as the calibrant [41]. Two dilutions were prepared for each replicate.

Prior to individual folate vitamer determination by UHPLC, sample extracts were purified and concentrated using affinity chromatography with folate-binding protein [42]. Folate vitamers were separated on an HSS T3 column $(1.8 \mu \mathrm{m}, 2.1 \times 150 \mathrm{~mm}$; Waters, EttenLeur, NB, The Netherlands) at $30^{\circ} \mathrm{C}$ with a gradient of acetonitrile and $30 \mathrm{mM}$ potassium phosphate buffer $(\mathrm{pH} 2.2)$ at a flow rate of $0.4 \mathrm{~mL} / \mathrm{min}$ [43]. Folate vitamers were detected by photodiode array and fluorescence detectors and quantified using external calibration curves as described by Edelmann et al. [43]. Folate analyses were performed in duplicates for two growing seasons (Y3, Y4).

\subsection{Statistical Analysis}

Statistica 10 software (StatSoft Inc., Tulsa, OK, USA) was used for statistical analysis. Analysis of variance (ANOVA) and Tukey's HSD multiple comparison test were used to identify significant differences at $p \leq 0.01$ and $p \leq 0.05$. 


\section{Results and Discussion}

\subsection{Evaluation of Phenotypic Traits and Weight of 1000 Seeds}

Crops can be bred for agronomic improvements such as yield, quality traits, and stress resistance. The differences in the tested phenotypic and morphological traits between the variety 'Zobor' and the reference variety Koniz are shown in Table S2. Distinctions were observed in six characteristics: color of the young leaf lower side, time of flowering, inflorescence color, time of plant maturity, anthocyanin coloration of stem base, and 1000seed weight.

Shape, size, and weight are the most easily identifiable characteristics of individual seeds [44]. In general, seed quality has a great influence on the economic production of agricultural crops. In amaranth, the most important physical quality trait and a critical factor in improving amaranth productivity is seed weight [12].

The 1000-seed weight was examined during four growing seasons (Y1-Y4). Although year, cultivar, and their interactions usually influence seed weight and yield, the $\gamma$-radiationderived variety 'Zobor' showed a significantly higher 1000-seed weight compared to the nonirradiated control K-433 in all periods studied (Figure 4). However, the 1000-seed weight values obtained for the hybrid 'Zobor' were similar to those obtained for the genotype Ficha.

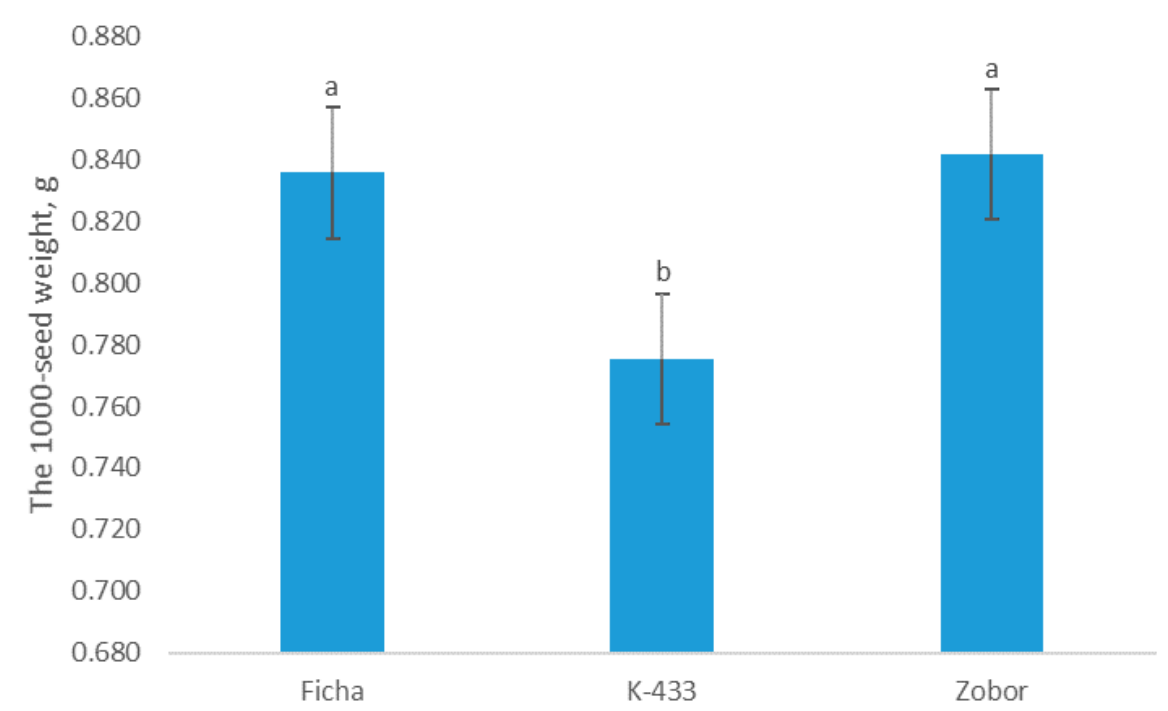

Figure 4. The 1000-seed weight in three amaranth genotypes over four cropping seasons. Results are presented as means ( \pm SE; standard error) for a 4 year period of three independent biological replicates per each variety per year. Different letters indicate significant differences according to Tukey's test $(p \leq 0.01)$.

Table 1 shows the values of 1000-seed weight of the evaluated grain amaranths. The lowest value of 1000-seed weight was observed in the control hybrid K-433 (0.73 g) in growing season 2, while the highest weight was noted in Ficha and 'Zobor' harvested in seasons 1 and 3 ( $0.92 \mathrm{~g}$ and $0.88 \mathrm{~g}$ for Ficha; $0.91 \mathrm{~g}$ and $0.87 \mathrm{~g}$ for 'Zobor'). Gimplinger et al. [12] tested the genotypes of $A$. hypochondriacus and A. cruentus L. with similar seed weights as reported in our study. Singh et al. [45] demonstrated that the seed weight of A. hypochondriacus varies between $0.62-0.88 \mathrm{~g}$, which is comparable to the K-433 values. However, Parveen et al. [28] estimated the average 1000-seed weight to be only $0.55 \mathrm{~g}$ for eight $A$. hybridus genotypes.

Pospišil et al. [46] reported an average 1000-seed weight of $0.65-0.73 \mathrm{~g}$ for two amaranth species, which was significantly increased by nitrogen fertilization in the dry season. Compared to the commercial grain varieties Plainsman $(0.71 \mathrm{~g})$ and Koniz $(0.69 \mathrm{~g})$, the hybrid variety 'Zobor' showed 1000-seed weight up to $18 \%$ and $21 \%$ higher, respectively [23]. From our results, it is evident that the growing season affects the studied yield parameter 
(Table 1), but the mutant variety 'Zobor' showed consistent performance over several growing seasons.

Table 1. The 1000-seed weight of amaranth samples tested during four growing seasons.

\begin{tabular}{lcccc}
\hline & A. cruentus L. & A. hypochondriacus $\times$ A. hybridus & \\
\cline { 2 - 5 } & Ficha & K-433 & 'Zobor' $^{{ }^{\prime}}$ & $\overline{\mathbf{x}} \pm$ SD \\
\hline Year 1 & $0.92^{\mathrm{a}}$ & $0.80^{\mathrm{bc}}$ & $0.91^{\mathrm{a}}$ & $0.87 \pm 0.06$ \\
Year 2 & $0.76^{\mathrm{cd}}$ & $0.73^{\mathrm{d}}$ & $0.76^{\mathrm{cd}}$ & $0.75 \pm 0.02$ \\
Year 3 & $0.88^{\mathrm{a}}$ & $0.80^{\mathrm{bc}}$ & $0.87^{\mathrm{a}}$ & $0.85 \pm 0.05$ \\
Year 4 & $0.80^{\mathrm{bc}}$ & $0.78^{\mathrm{cd}}$ & $0.83^{\mathrm{b}}$ & $0.80 \pm 0.03$ \\
\hline
\end{tabular}

Different letters indicate significant differences according to Tukey's test $(p \leq 0.01)$. Results are the means for four growing seasons of 10 independent biological replicates per each variety per year.

The increased seed size and yield could have a negative impact on the nutritional properties of amaranth seeds [47]. However, our previous studies [22,23,48] showed high nutritional quality of the amaranth germplasm obtained by $\gamma$-radiation with higher seed weight.

\subsection{Morphological and Morphometric Characterization of the Seeds}

The seeds of amaranth are lenticular and about $1 \mathrm{~mm}$ in diameter. They vary in color from white to creamish yellow, reddish, dark brown, and black [28-30,45,49].

Here, the morphology of amaranth seeds was studied by light microscopy and toluidine blue $\mathrm{O}$ staining (Figure 5). The mature amaranth seed consists of a large, nutrient-rich perisperm (full of polygonal starch cells) surrounded by a peripheric embryo, which is consistent with previous observations described by other authors [30,31]. The seed coat, cotyledons, and shoot apical meristem are also clearly visible in the taken images. According to our observations, the morphology of the 'Zobor' seeds remained unchanged and corresponded to the morphology of nonirradiated amaranth seeds.

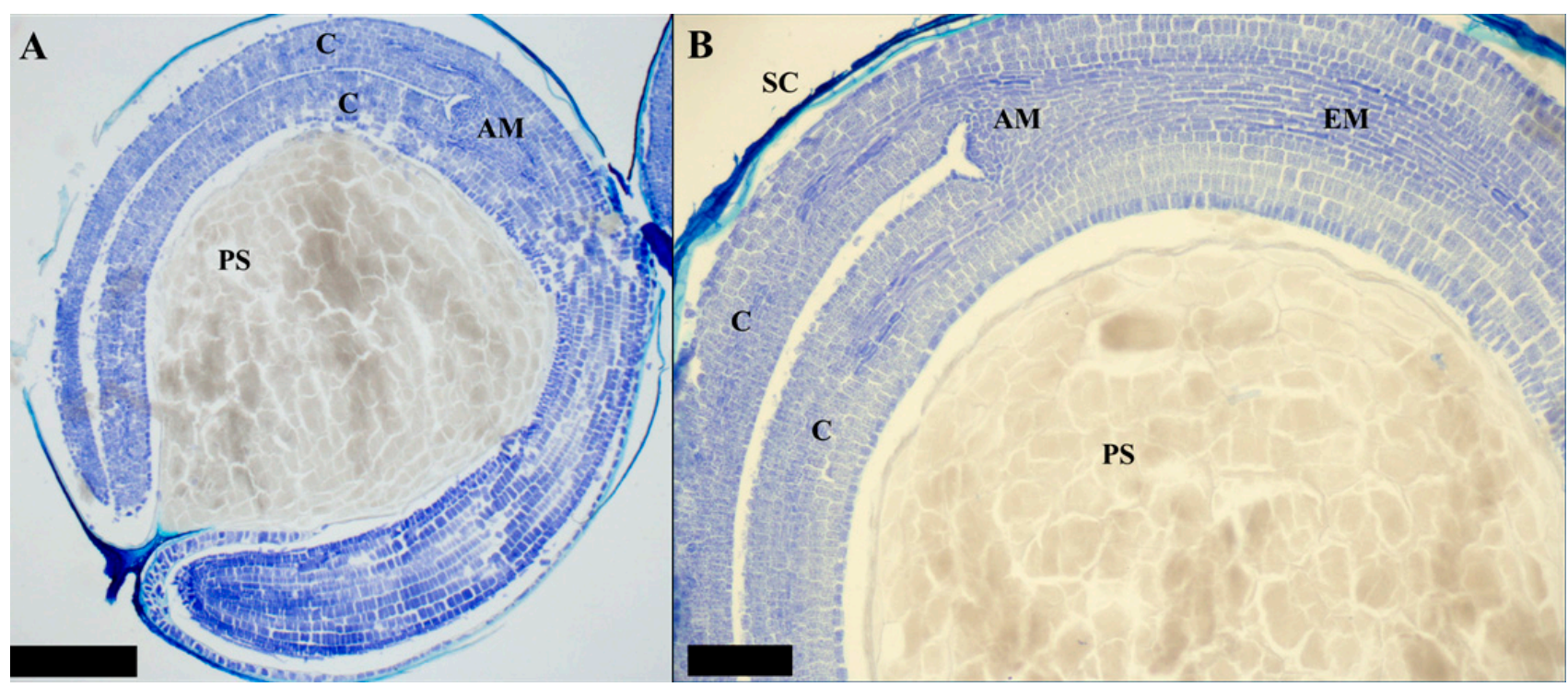

Figure 5. Light microscopy of an amaranth seed section stained with toluidine blue O. (A) General view of seed in longitudinal section; (B) higher magnification of the seed shows detailed morphology: the seed coat, starchy perisperm, cotyledons, and shoot apical meristem are clearly visible. AM, apical meristem; C, cotyledon; EM, embryo axis; PS, perisperm; SC, seed coat. Scale bar: $500 \mu \mathrm{m}(\mathbf{A})$ and $200 \mu \mathrm{m}(\mathbf{B})$.

Seed size is another important characteristic for agricultural practice and the interest of crop breeders. Seed size may be used to distinguish some species within amaranth 
genotypes that are otherwise morphologically very similar. The present work shows that the Slovak mutant variety 'Zobor' with a long-term higher 1000-seed weight has visually larger seeds than the untreated control K-433 (Figure 6).
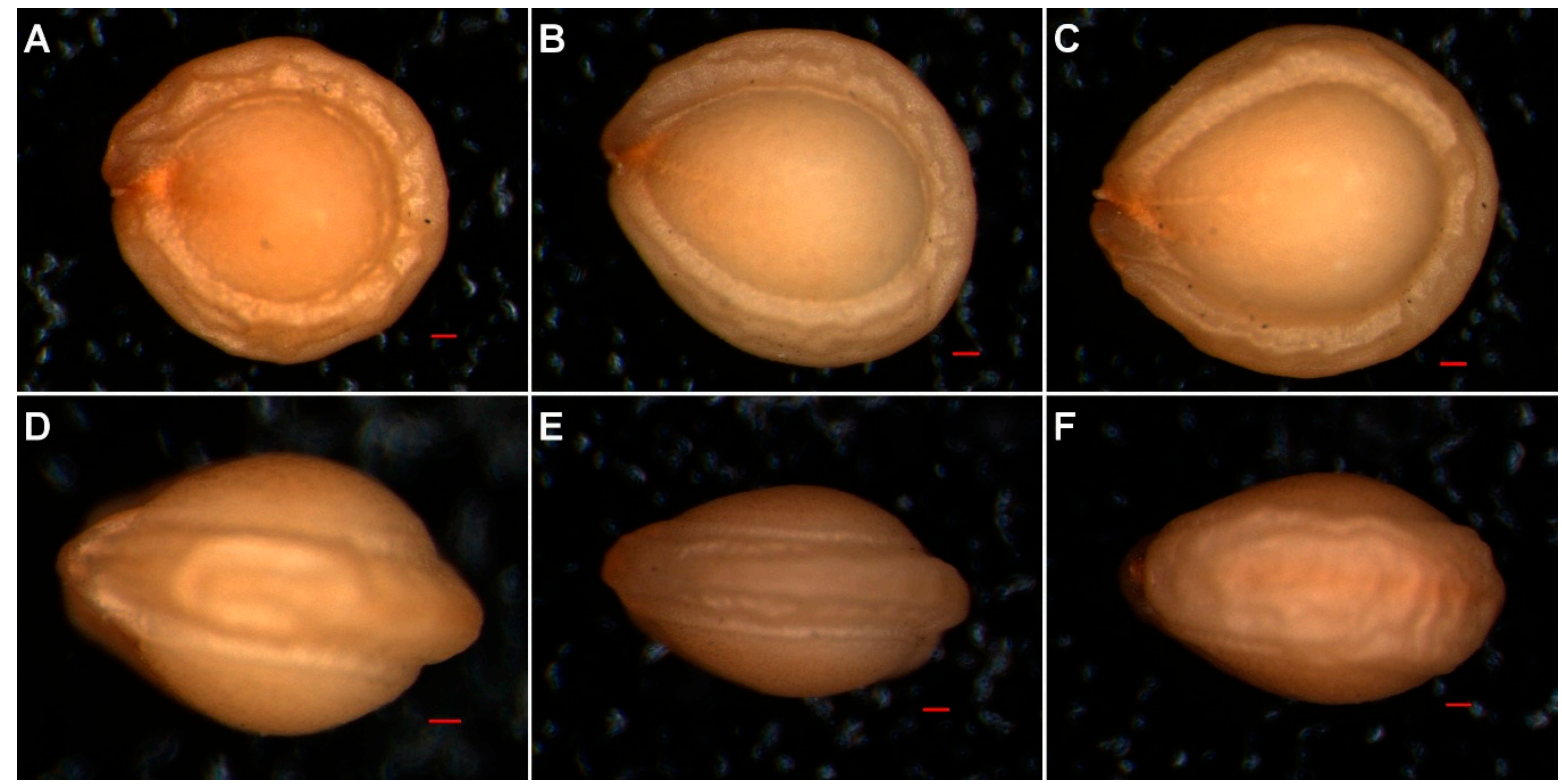

Figure 6. Visualization of the dorsal (A-C) and ventral (D-F) sides of amaranth seeds: (A,D) genotype Ficha; (B,E) hybrid K-433; (C,F) Slovak variety 'Zobor' Scale bar: $100 \mu \mathrm{m}$.

Statistical analysis of seed morphometric parameters confirmed that 'Zobor' had significantly greater seed area, bound height, radius and perimeter on the dorsal side of the whole seed, and bound height on the ventral side of the seed compared to the control K-433 (Table 2). Moreover, the variety 'Zobor' exhibited an increase in some seed morphometric parameters over genotype Ficha (Table 2).

Table 2. Morphometric parameters measured on whole seed of dorsal and ventral side.

\begin{tabular}{ccccccc}
\hline Sample & Area $\left(\mathbf{m m}^{\mathbf{2}}\right)$ & $\begin{array}{c}\text { Bound Width } \\
\mathbf{( m m )}\end{array}$ & $\begin{array}{c}\text { Bound } \\
\text { Height-Dorsal } \\
\text { Side }(\mathbf{m m})\end{array}$ & $\begin{array}{c}\text { Bound } \\
\text { Height-Ventral } \\
\text { Side }(\mathbf{m m})\end{array}$ & $\begin{array}{c}\text { Radius } \\
(\mathbf{m m})\end{array}$ & $\begin{array}{c}\text { Perimeter } \\
(\mathbf{m m})\end{array}$ \\
\hline Ficha & $1.39^{\mathrm{ab}}$ & $1.37^{\mathrm{b}}$ & $1.31^{\mathrm{a}}$ & $0.88^{\mathrm{a}}$ & $1.33^{\mathrm{ab}}$ & $4.58^{\mathrm{b}}$ \\
K-433 & $1.37^{\mathrm{b}}$ & $1.45^{\mathrm{a}}$ & $1.25^{\mathrm{b}}$ & $0.84^{\mathrm{b}}$ & $1.32^{\mathrm{b}}$ & $4.58^{\mathrm{b}}$ \\
'Zobor' & $1.44^{\mathrm{a}}$ & $1.48^{\mathrm{a}}$ & $1.29^{\mathrm{a}}$ & $0.87^{\mathrm{a}}$ & $1.35^{\mathrm{a}}$ & $4.73^{\mathrm{a}}$ \\
\hline
\end{tabular}

Different letters indicate significant differences according to Tukey's test $(p \leq 0.05)$ in the same column. Results are the means of fifty independent biological replicates per each genotype.

As for the perisperm, 'Zobor' had higher values in area, bound width, bound height, and perimeter compared to control K-433, and higher area, bound width, and perimeter than genotype Ficha (Table 3). There were no significant differences in pericarp area among the amaranths studied.

Table 3. Morphometric parameters measured on seed perisperm and pericarp of dorsal side.

\begin{tabular}{cccccc}
\hline \multirow{2}{*}{ Sample } & \multicolumn{2}{c}{ Perisperm } & \multicolumn{2}{c}{ Pericarp } \\
\cline { 2 - 6 } & Area $\left(\mathbf{m m}^{\mathbf{2}}\right)$ & Bound Width $\mathbf{( m m )}$ & Bound Height $(\mathbf{m m})$ & Perimeter $(\mathbf{m m})$ & Area $\left._{(\mathbf{m m}}{ }^{\mathbf{}}\right)$ \\
\hline Ficha & $0.68^{\mathrm{b}}$ & $0.98^{\mathrm{c}}$ & $0.91^{\mathrm{a}}$ & $2.97^{\mathrm{b}}$ & 0.70 \\
K-433 & $0.66^{\mathrm{b}}$ & $1.05^{\mathrm{b}}$ & $0.84^{\mathrm{b}}$ & $2.96^{\mathrm{b}}$ & 0.71 \\
'Zobor' & $0.72^{\mathrm{a}}$ & $1.08^{\mathrm{a}}$ & $0.89^{\mathrm{a}}$ & $3.08^{\mathrm{a}}$ & 0.72 \\
\hline
\end{tabular}

Different letters indicate significant differences according to Tukey's test $(p \leq 0.05)$ in the same column. Results are the means of 50 independent biological replicates per each genotype. 
Morphometric characterization of amaranth seeds has not been explored so much. Parveen et al. [28] observed wide variation (considerable diversity) in seed size, shape, color, and weight in eight amaranth genotypes. The measured seed length and width averaged $1.09 \mathrm{~mm}$ and $0.98 \mathrm{~mm}$, respectively. Nevertheless, the study of seed morphology and anatomy could contribute and provide useful data for species differentiation and taxonomy classification.

\subsection{Starch Analysis}

Starch is the most abundant carbohydrate in amaranth grain. Amaranth starch has low amylose content, ranging from $2 \%$ to $12 \%$ depending on the genotype, while amylopectin content is about $90 \%$ to $98 \%$ [45]. The ratio of amylose and amylopectin affects the physical and chemical properties of starch. Furthermore, a very low amylose content indicates a waxy type of starch. Amaranth amylopectin consists of short-chain branched glucans with an average molecular weight of $11.8 \times 10^{6} \mathrm{~g} \cdot \mathrm{mol}^{-1}$ [50]. The small size of the amaranth starch grain, as well as its high amylopectin content, explains most of the physical properties of amaranth starch. The amylose content correlates significantly with the functional properties, including pasting, thermal properties, and texture, and it appears to be an important determinant of these properties. Considering these facts, amaranth starch shows good gelatinization properties and freeze/thaw stability, which are appreciated in the food industry $[27,51,52]$.

The determination of amylose content, starch swelling power, particle size analysis, and pasting properties in seeds of genotype Ficha, mutant variety 'Zobor', and control K-433 was performed. The amylose content in the analyzed amaranth seeds ranged from $3.80 \%$ to $3.93 \%$ (Table 4 ). Similar values of amylose concentration were found by Hoover [53], Choi et al. [54], Chandla et al. [55], Condés et al. [56], and Yuan et al. [57]. Macrone [58] detected 4.1\% amylose content in the commercially preferred variety Plainsman, but Baker et al. [59] reported that Plainsman starch does not contain amylose. Although we noted the effect of growing season on amylose content, no significant difference was observed between genotypes over the period tested.

Table 4. Amylose content, granule size, and swelling properties of starches from three amaranth genotypes.

\begin{tabular}{|c|c|c|c|}
\hline Sample & Amylose, \% & Particle Size, $\mu \mathrm{M}$ & Swelling Test, $\mathrm{g} \cdot \mathrm{g}^{-1}$ \\
\hline Ficha & 3.89 & $1.44^{\mathrm{b}}$ & 9.66 \\
\hline $\mathrm{K}-433$ & 3.93 & $1.49^{\mathrm{a}}$ & 10.07 \\
\hline 'Zobor' & 3.80 & $1.32^{\mathrm{c}}$ & 9.26 \\
\hline
\end{tabular}

Different letters indicate significant differences according to Tukey's test $(p \leq 0.01)$ in the same column. Results are the means for four growing seasons of four independent biological replicates per each variety per year.

The size of starch grains and their geometric features differ between plant species and may influence the functional and physicochemical properties of starch [8]. As reported by Lindeboom et al. [60], there is limited information on the genetic control of starch granule size.

The particle analyzer was employed to study the size of amaranth starch granule size, and some differences in the granule size distribution were identified (Figure 7). The highest value of small starch granules $(0-0.95 \mu \mathrm{m})$ was found in 'Zobor' $(16.45 \%)$ compared to Ficha $(11.53 \%)$ and control K-433 (4.11\%). The volume-weighted mean size of investigated amaranth starch was $1.42 \mu \mathrm{m}$, which is in agreement with previous studies [52,61]. The mutant variety 'Zobor' had significantly smaller average granule size compared to the control hybrid K-433 and genotype Ficha (Table 4). Similarly, Wang et al. [62] investigated smaller starch granules in rice mutant lines compared to wild type. Macrone [58] examined a starch granule diameter of $1 \mu \mathrm{m}$ in $A$. pumilus and A. hypochondriacus. We assume that the smaller size of starch granules of 'Zobor' compared to the nonirradiated control K-433 
is compensated for by their higher content, but this needs to be verified by more detailed morphological analysis.

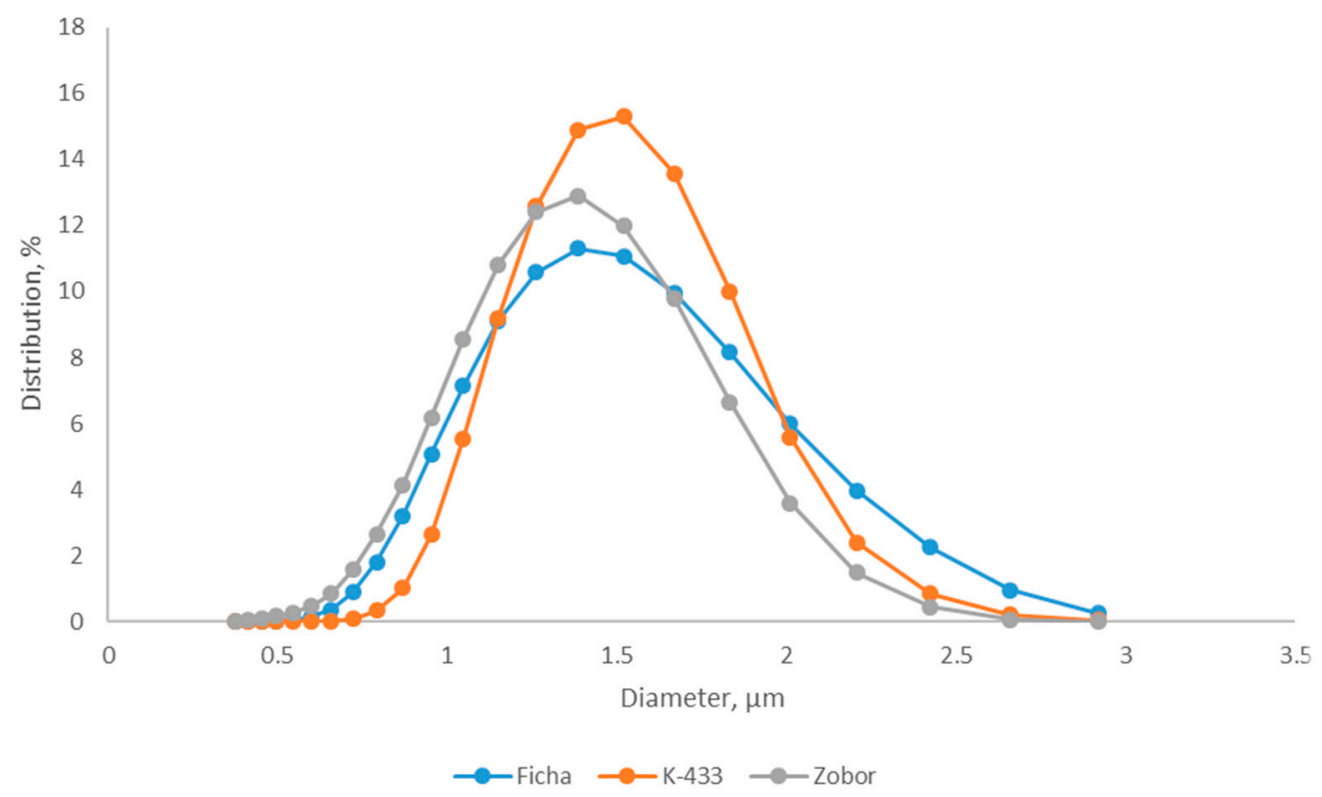

Figure 7. Granule size distribution of starch in evaluated amaranth samples.

Gelatinization of starch is a process in which water disperses into the starch granule and causes swelling due to hydration of the amorphous phase, resulting in loss of crystallinity and molecular order. Depending on the origin of the starch, there is a specific temperature range for gelatinization related to the starch of each origin. The gelling ability of starch is of great importance in food production, and the textural properties of starch gels are used to evaluate the behavior of starch in food systems [63].

The starch swelling test is a simple, inexpensive laboratory method for measuring water absorption during gelatinization of starch [37]. Starch swelling power is related to grain structure and chemical composition, especially amylose and lipid content, rather than granule size $[60,61]$.

In this case, no statistically significant difference in starch swelling power was found among the studied amaranth cultivars (Table 4). The average value of starch swelling power of amaranth was $9.66 \mathrm{~g} \cdot \mathrm{g}^{-1}$. Similar values were reported by Chandla et al. [55] who analyzed the starch swelling power of four different amaranth cultivars with values ranging from 8.10 to $10.29 \mathrm{~g} \cdot \mathrm{g}^{-1}$. Choi et al. [54] compared the swelling power of amaranth starch with that of waxy sorghum and waxy millet starch, with the greatest difference observed at temperatures above $75^{\circ} \mathrm{C}$. It was confirmed that the swelling power of waxy starches has higher values than normal starches. Kong et al. [52] investigated this starch property in 15 amaranth cultivars at different temperatures. The authors reported a swelling power at $85{ }^{\circ} \mathrm{C}$ ranging from 9.1 to $20 \mathrm{~g} \cdot \mathrm{g}^{-1}$. The swelling power of native and processed $A$. hypochondriacus flour studied by Siwatch et al. [64] ranged from 3.58 to $7.55 \mathrm{~g} \cdot \mathrm{g}^{-1}$, with the swelling power decreasing after processing.

Starch gelatinization is influenced by amylose content and starch granule size. The gelatinization properties of amaranth starch may vary depending on the species and cultivars [65].

The pasting properties of three amaranth genotypes were determined using a Rapid Visco Analyzer (Table 5). The RVA profiles of 'Zobor', Ficha, and K-433 are shown in Figures S2-S4.

The mutant cultivar 'Zobor' had the significantly lowest pasting temperature, viscosity peak, holding strength, and final viscosity compared to Ficha and the control K-433 (Table 5). The pasting temperature of amaranth flour ranged from 70.18 to $74.25^{\circ} \mathrm{C}$. Chandla et al. [61] 
reported the pasting temperature and peak viscosity of A. hypochondriacus Druga as $74.31^{\circ} \mathrm{C}$ and $1718.00 \mathrm{cP}$, respectively. Yuan et al. [57] investigated the pasting and gelling properties of amaranth flour and found similar average values for peak viscosity, holding strength, and final viscosity at $95^{\circ} \mathrm{C}$ to those obtained in our study. The authors compared waxy and normal commercial flours at high heating temperatures, and the starch content of the flours was positively correlated with their peak and breakdown viscosities.

Table 5. Pasting properties of starches from three amaranth cultivars.

\begin{tabular}{cccccccc}
\hline Sample & $\begin{array}{c}\text { Peak } \\
\text { Temperature, }{ }^{\circ} \mathbf{C}\end{array}$ & $\begin{array}{c}\text { Peak Viscosity, } \\
\mathbf{c P}\end{array}$ & Hold, cP & $\begin{array}{c}\text { Breakdown, } \\
\mathbf{c P}\end{array}$ & Final, cP & $\begin{array}{c}\text { Setback, cP } \\
\text { Peak Time, } \\
\text { min }\end{array}$ \\
\hline Ficha & $74.25^{\mathrm{b}}$ & $1153.50^{\mathrm{a}}$ & $987.50^{\mathrm{a}}$ & 166.00 & $1153.50^{\mathrm{a}}$ & 166.00 & 4.95 \\
K-433 $^{\text {a }}$ & $75.50^{\mathrm{a}}$ & $1059.50^{\mathrm{a}}$ & $924.00^{\mathrm{a}}$ & 135.50 & $1077.50^{\mathrm{a}}$ & 153.50 & 5.09 \\
\hline
\end{tabular}

Different letters indicate significant differences according to Tukey's test $(p \leq 0.01)$ in the same column. Results are the means for one growing season of two independent biological replicates. $\mathrm{cP}$, centipoise.

Previous reports [66-68] suggested that starch properties can be affected by radiation as a processing technology. The $\gamma$-irradiation hydrolyzes the chemical bonds of starch, which leads to the decomposition of the polymer chain. The subsequently modified starch, characterized by increased solubility or decreased viscosity, can be used in the paper and textile industries. Kong et al. [68] studied the effect of $\gamma$-radiation on the rheological properties of amaranth starch and found that the viscosity of starch decreased with increasing radiation dose. Irradiation even affected the temperature properties and crystallization of the starch. The results achieved by Kong et al. [69] showed that mutation breeding based on $\gamma$-irradiation is an efficient way to obtain novel starch sources for various food and nonfood applications, which have the potential to replace chemically modified starches.

We can conclude that $\gamma$-irradiation could induce a change in starch particle size and pasting properties in the variety 'Zobor', although the amylose content and the swelling power were maintained.

\subsection{Folate}

The results of the determination of total folate and the distribution of the six folate vitamers in amaranth seeds are provided in Table 6. To obtain consistent data, two methods were used to determine the folate content-microbiological assay (MA) and ultrahighperformance liquid chromatography (UHPLC). The UHPLC values of total folate content could be lower compared to the microbiological values due to some unidentified folate compounds, whereas MA may give a response to non-folate compounds [42].

Table 6. Total folate content and folate vitamer proportions in amaranth seeds.

\begin{tabular}{|c|c|c|c|c|c|c|c|c|}
\hline \multirow{2}{*}{ Sample } & \multicolumn{2}{|c|}{$\begin{array}{c}\text { Folate Content, } \\
\mathrm{ng} \cdot \mathrm{g}^{-1} \mathrm{FW}\end{array}$} & \multicolumn{6}{|c|}{ Folate Vitamer Proportions, \% } \\
\hline & MA & UPLC & THF & $\begin{array}{c}5-\mathrm{CH}_{3}- \\
\mathrm{H}_{4}\end{array}$ & 10-CHO-PGA & 5-CHO- ${ }_{4}$ & $5,10-\mathrm{CH}^{+}-\mathrm{H}_{4}$ & PGA \\
\hline Ficha & $909.00^{b}$ & $824.50^{b}$ & 1.50 & 15.40 & $13.40^{\mathrm{ab}}$ & 43.30 & 10.40 & $16.00^{a b}$ \\
\hline K-433 & $952.50 \mathrm{ab}$ & $782.50^{\mathrm{c}}$ & 1.20 & 17.80 & $14.30^{\mathrm{a}}$ & 44.50 & 6.00 & $16.20^{\mathrm{a}}$ \\
\hline 'Zobor' & $999.50^{\mathrm{a}}$ & $936.00^{a}$ & 2.10 & 19.40 & $12.60^{b}$ & 41.70 & 10.10 & $14.00^{b}$ \\
\hline
\end{tabular}

Different letters indicate significant differences according to Tukey's test $(p \leq 0.01)$ in the same column. Results are the means of duplicate analyses for two growing seasons. FW, fresh weight; THF, tetrahydrofolate; $5-\mathrm{CH}_{3}-\mathrm{H}_{4}, 5$-methyltetrahydrofolate; 10-CHO-PGA, 10-formylfolic acid; 5-CHO- $\mathrm{H}_{4}$, 5-formyltetrahydrofolate; 5,10- $\mathrm{CH}^{+}-\mathrm{H}_{4}, 5,10$-methenyltetrahydrofolate; PGA, folic acid.

The highest average folate content $\left(999.50 \mathrm{ng} \cdot \mathrm{g}^{-1} \mathrm{FW} / \mathrm{MA}\right.$ and $936.00 \mathrm{ng} \cdot \mathrm{g}^{-1} \mathrm{FW} /$ UHPLC) was obtained for the mutant variety 'Zobor', which is similar to the findings 
reported by Soriano-García et al. [70]. However, when comparing our results with older studies, higher values were obtained, such as those of Schoenlechner et al. [6]. The authors determined the total folate content from 528 to $730 \mathrm{ng} \cdot \mathrm{g}^{-1} \mathrm{ng} \cdot \mathrm{g}^{-1} \mathrm{DW}$ in a flour of four amaranth varieties. Furthermore, amaranth samples in our study had higher folate content than described for oat grains [43], rye [42], and many cereal products [71], but lower than buckwheat and quinoa [72].

Folate is known to be an unstable vitamin, with $35-70 \%$ loss due to storage and processing [6]. Motta et al. [73] investigated the effects of processing on folate content in amaranth. The authors found that boiling and steaming reduced total folate content by $58 \%$ and $22 \%$, respectively. Schoenlechner et al. [6] also determined the total folate loss in processed amaranth products such as bread, cookies, and pasta, and the folate loss in cookies was the lowest.

There is a lack of literature dealing with the distribution of folate vitamers. Here, we identified tetrahydrofolate (THF), 5-methyltetrahydrofolate $\left(5-\mathrm{CH}_{3}-\mathrm{H}_{4}\right), 10$-formylfolic acid (10-CHO-PGA), 5-formyltetrahydrofolate (5-CHO- $\left.\mathrm{H}_{4}\right), 5,10$-methenyltetrahydrofolate $\left(5,10-\mathrm{CH}^{+}-\mathrm{H}_{4}\right)$, and folic acid (PGA) as naturally occurring folate derivatives in amaranth seeds. The major vitamer in all three amaranth samples was $5-\mathrm{CHO}-\mathrm{H}_{4}$, and the next abundant vitamers were $5-\mathrm{CH}_{3}-\mathrm{H}_{4}, \mathrm{PGA}$, and 10-CHO-PGA (Figure 8). 5- $\mathrm{CHO}-\mathrm{H}_{4}$, which is considered rather stable, is also the predominant vitamer in cereal products [71]. Motta et al. [73] identified 5- $\mathrm{CH}_{3}-\mathrm{H}_{4}$ as the most abundant form of folate in amaranth, quinoa, and buckwheat. However, the authors detected only three folate vitamers. Folic acid is usually present in very small amounts in natural products. We suppose that the relatively high folic acid content determined here occurred mainly due to storage and sample preparation.

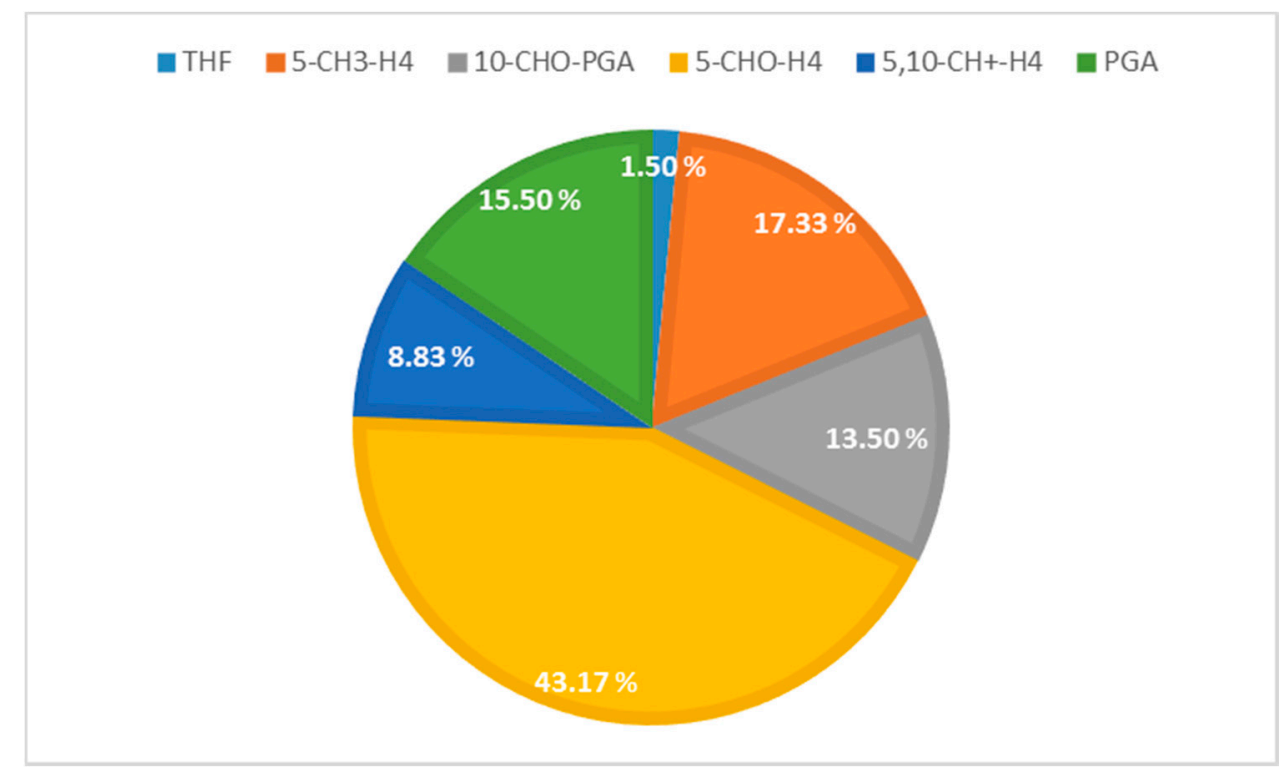

Figure 8. Frequency and distribution of folate vitamers in amaranth seeds. THF, tetrahydrofolate; 5- $\mathrm{CH}_{3}-\mathrm{H}_{4}$, 5-methyltetrahydrofolate; 10-CHO-PGA, 10-formylfolic acid; 5-CHO-H 4 , 5formyltetrahydrofolate; 5,10- $\mathrm{CH}^{+}-\mathrm{H}_{4}, 5,10$-methenyltetrahydrofolate; PGA, folic acid.

Our results show that the variety 'Zobor' has the highest total folate content among the tested amaranths. Therefore, fortification of cereal products with this amaranth flour is an interesting approach to enrich the final product and increase its folate content.

\section{Conclusions}

Comparative analysis of the Slovak mutant variety 'Zobor', nonirradiated hybrid $\mathrm{K}-433$, and genotype Ficha revealed changes in some agronomic, morphometric, and 
nutritional seed traits. The irradiation developed variety 'Zobor' showed consistent performance in the important quantitative trait 1000-seed weight, which was significantly higher than in the control grain amaranth. Moreover, the seeds of the mutant variety were significantly larger compared to the control seeds of hybrid K-433 and genotype Ficha, as evidenced by several increased morphometric parameters. Changes in starch particle size and pasting properties were observed in 'Zobor' seeds, although amylose content and swelling power were not altered. 'Zobor' had the highest folate contents, with similar vitamer distribution to the other two samples. To sum up, the current study showed that the mutant variety 'Zobor' represents stable, potentially high-yielding variety with high folate content.

Supplementary Materials: The following are available online at https:/ /www.mdpi.com/article/10 .3390 /agronomy11122565/s1: Figure S1. Meteorological conditions during four amaranth cropping seasons in locality Nitra; Figure S2. Pasting properties of Slovak amaranth variety 'Zobor' obtained with Rapid Visco Analyzer (RVA, Model 3D, Newport Scientific); Figure S3. Pasting properties of genotype Ficha obtained with Rapid Visco Analyzer (RVA, Model 3D, Newport Scientific); Figure S4. Pasting properties of hybrid K-433 obtained with Rapid Visco Analyzer (RVA, Model 3D, Newport Scientific); Table S1. Parameters measured on the amaranth seeds; Table S2. Differences of phenotypic traits between reference variety Koniz and new variety 'Zobor'.

Author Contributions: Conceptualization, A.H. and A.G.; methodology, M.S.; investigation, M.S., V.M., S.K., J.N. and J.F.; writing—original draft preparation, M.S.; writing—review and editing, A.H., V.M. and A.G.; statistical analysis, J.G.; supervision, A.H. and M.S. All authors have read and agreed to the published version of the manuscript.

Funding: This publication was supported by the Operational Program Integrated Infrastructure within the project: Demand-driven research for the sustainable and innovative food, Drive4SIFood 313011V336, co-financed by the European Regional Development Fund.

Acknowledgments: We would like to thank Fred Stoddard (University of Helsinki, Finland) for cooperation with starch analysis.

Conflicts of Interest: The authors declare no conflict of interest.

\section{References}

1. Assad, R.; Reshi, Z.A.; Jan, S.; Rashid, I. Biology of Amaranths. Bot. Rev. 2017, 83, 382-436. [CrossRef]

2. Jacobsen, S.E.; Mujica, A.; Guarino, L. The genetic resources of the Andean grain crop amaranth (Amaranthus caudatus L., A. cruentus L. and A. hipochondriacus L.). In Proceedings of the International Conference on Science and Technology for Managing Plant Genetic Diversity in the Twenty-First Century, Kuala Lumpur, Malaysia, 12-16 June 2000.

3. Osei-Kwarteng, M.; Brenner, D.M. A review of taxonomic inventory of amaranths (Amaranthus spp. L.) in Ghana: An outlook towards characterization of local amaranths. Acad. Lett. 2021, 2037, 1-4. [CrossRef]

4. Andini, R.; Sulaiman, M.; Kadapi, M.; Ohsawa, R. Polyploidy and Hybridization for Amaranth Crop Improvement. In The Amaranth Genome. Compendium of Plant Genomes, 1st ed.; Adhikary, D., Deyholos, M.K., Délano-Frier, J., Eds.; Springer Nature Switzerland AG: Cham, Switzerland, 2021; pp. 151-166. [CrossRef]

5. Farvin, K.H.S.; Anandan, R.; Kumar, S.H.S.; Shiny, K.S.; Mathew, S.; Sankar, T.V.; Nair, P.G.V. Cardioprotective effect of squalene on lipid profile in isoprenaline-induced myocardial infarction in rats. J. Med. Food 2006, 9, 531-536. [CrossRef]

6. Schoenlechner, R.; Wendner, M.; Siebenhandl-Ehn, S.; Berghofer, E. Pseudocereals as alternative sources for high folate content in staple foods. J. Cereal Sci. 2010, 52, 475-479. [CrossRef]

7. Alegbejo, J.O. Nutritional value and utilization of amaranthus (Amaranthus spp.)—A review. Bayero J. Pure Appl. Sci. 2013, 6, 136-143. [CrossRef]

8. Venskutonis, P.R.; Kraujalis, P. Nutritional components of amaranth seeds and vegetables: A review on composition, properties and uses. Compr. Rev. Food Sci. Food Saf. 2013, 12, 381-412. [CrossRef]

9. Scotti, M.; Stella, L.; Shearer, E.J.; Stover, P.J. Modeling cellular compartmentation in one-carbon metabolism. Wiley Interdiscip. Rev. Syst. Biol. Med. 2013, 5, 343-365. [CrossRef] [PubMed]

10. Williams, J.; Mai, C.T.; Mulinare, J.; Isenburg, J.; Flood, T.J.; Ethen, M.; Frohnert, B.; Kirby, R.S. Updated estimates of neural tube defects prevented by mandatory folic acid fortification-United States, 1995-2011. MMWR Morb. Mortal. Wkly. Rep. 2015, 64, 1-5. [PubMed]

11. Krawinkel, M.B.; Strohm, D.; Weissenborn, A.; Watzl, B.; Eichholzer, M.; Bärlocher, K.; Elmadfa, I.; Leschnik-Bonnet, E.; Heseker, H. Revised D-A-CH intake recommedation for folate: How much is needed? Eur. J. Clin. Nutr. 2014, 68, 719-723. [CrossRef] [PubMed] 
12. Gimplinger, D.M.; Dobos, G.; Schönlechner, R.; Kaul, H.P. Yield and quality of grain amaranth (Amaranthus sp.) in Eastern Austria. Plant Soil Environ. 2007, 53, 105-112. Available online: https://www.agriculturejournals.cz/publicFiles/00059.pdf (accessed on 25 October 2021). [CrossRef]

13. Brenner, D.M.; Baltensperger, D.D.; Kulakow, P.A.; Lehmann, J.W.; Myers, R.L.; Slabbert, M.M.; Sleugh, B.B. Genetic resources and breeding of Amaranthus. In Plant Breeding Reviews; Janick, J., Ed.; John Wiley \& Sons, Inc.: New York, NY, USA, 2000; Volume 19, pp. 227-285. [CrossRef]

14. Brenner, D.M. Non-shattering grain amaranth populations. In Trends in New Crops and New Uses; Janick, J., Whipkey, A., Eds.; ASHS Press: Alexandria, VA, USA, 2002; pp. 104-106.

15. Lehmann, J.; Clark, R.; Frey, K. Biomass heterosis and combining ability in interspecific and intraspecific matings of grain amaranths. Crop Sci. 1991, 31, 1111-1116. [CrossRef]

16. Stetter, M.G.; Zeitler, L.; Steinhaus, A.; Kröner, K.; Biljecki, M.; Schmid, K.J. Crossing methods and cultivation conditions for rapid production of segregating populations in three grain amaranth species. Front. Plant Sci. 2016, 7, 816. [CrossRef]

17. Schmidhuber, J.; Tubiello, F.N. Global food security under climate change. Proc. Natl. Acad. Sci. USA 2007, 104, 19703-19708. [CrossRef]

18. Andini, R. Breeding amaranth for enhanced nutritional values; Emphasizing on protein content. In Antioxidant Properties of Vegetable Crops; Singh, S., Singh, R., Thakur, N., Eds.; Jaya Publishing House: Delhi, India, 2018; pp. 251-276.

19. Gajdošová, A.; Libiaková, G.; Fejér, J. Improvement of selected Amaranthus cultivars by means of mutation induction and biotechnological approaches. In Breeding of Neglected and Under-Utilized Crops, Spices and Herbs; Science Publishers: Enfield, NH, USA, 2007; pp. 151-169. Available online: http://www-pub.iaea.org/MTCD/publications/PDF/te_1426_web.pdf (accessed on 2 November 2021).

20. Kečkešová, M.; Gálová, Z.; Hricová, A. Changes of protein profiles in amaranth mutant lines. J. Microbiol. Biotechnol. Food Sci. 2012, 1, 1129-1135.

21. Kečkešová, M.; Palenčárová, E.; Gálová, Z.; Gažo, J.; Hricová, A. Nutritional quality of grain amaranths (Amaranthus L.) compared to putative mutant lines. J. Microbiol. Biotechnol. Food Sci. 2013, 2, 1716-1724.

22. Hricová, A.; Fejér, J.; Libiaková, G.; Szabóová, M.; Gažo, J.; Gajdošová, A. Characterization of phenotypic and nutritional properties of valuable Amaranthus cruentus L. mutants. Turk. J. Agric. For. 2016, 40, 761-771. [CrossRef]

23. Szabóová, M.; Záhorský, M.; Gažo, J.; Geuens, J.; Vermoesen, A.; D’Hondt, E.; Hricová, A. Differences in seed weight, amino acid, fatty acid, oil, and squalene content in $\gamma$-irradiation-developed and commercial amaranth varieties (Amaranthus spp.). Plants 2020, 9, 1412. [CrossRef] [PubMed]

24. Maluszynski, M.; Szarejko, I.; Bathia, C.; Nichterlein, K.; Lagoda, P. Methodologies for generating variability. Part 4: Mutation techniques. In Plant Breeding and Farmer Participation; Ceccarelli, S., Guimarães, E.P., Wrltzien, E., Eds.; Food and Agriculture Organization of the United Nations: Rome, Italy, 2009; pp. 159-194.

25. Castellanos-Arévalo, A.P.; Cabrera-Ponce, J.L.; Nava-Sandoval, C.; Délano-Frier, J.P. How to Overcome Recalcitrance? Novel Strategies and Recent Advances in the Genetic Transformation of Grain Amaranth. In The Amaranth Genome, Compendium of Plant Genomes; Adhikary, D., Deyholos, M.K., Délano-Frier, J.P., Eds.; Springer Nature Switzerland AG: Cham, Switzerland, 2021; pp. 125-149. [CrossRef]

26. Gomez-Pando, L. Development of improved varieties of native grains through radiation-induced mutagenesis. In Mutagenesis: Exploring Novel Genes and Pathways; Tomlekova, N.B., Kozgar, M.I., Wani, M.R., Eds.; Wageningen Academic Publishers: Wageningen, The Netherlands, 2014; pp. 105-124. [CrossRef]

27. Mlakar, S.G.; Turinek, M.; Jakop, M.; Bavec, M.; Bavec, F. Grain amaranth as an alternative and perspective crop in temperate climate. J. Geogr. 2010, 5, 135-145.

28. Parveen, M.; Srijata, M.; Tah, J.; Chattopadhyay, N.C.H. Study of intraspecies variation in seed coat micro-morphology of Amaranthus hybridus by scanning electron microscope. Int. J. Plant Breed. Genet. 2015, 9, 198-205. [CrossRef]

29. Irving, D.W.; Betschart, A.A.; Saunders, R.M. Morphological studies on Amaranthus cruentus. J. Food Sci. 1981, 46, 1170-1174. [CrossRef]

30. Ninfali, P.; Panato, A.; Bortolotti, F.; Valentini, L.; Gobbi, P. Morphological analysis of the seeds of three pseudocereals by using light microscopy and ESEM-EDS. Eur. J. Histochem. 2020, 64, 3075. [CrossRef] [PubMed]

31. Coimbra, S.; Salema, R. Amaranthus hypochondriacus: Seed structure and localization of seed reserves. Ann. Bot. 1994, 74, 373-379. [CrossRef]

32. UPOV. General Introduction to the Examination of Distinctness, Uniformity and Stability and the Development of Harmonized Descriptions of New Varieties of Plants; TG/1/3. 2002. Available online: https://www.upov.int/en/publications/tg-rom/tg001 /tg_1_3.pdf (accessed on 20 October 2021).

33. Schneider, C.A.; Rasband, W.S.; Eliceiri, K.W. NIH Image to ImageJ: 25 years of image analysis. Nat. Methods 2012, 9, 671-675. [CrossRef] [PubMed]

34. Resio, N.A.C.; Tolaba, P.M.; Suárez, C. Correlations between wet-milling characteristics of amaranth grain. J. Food Eng. 2009, 92, 275-279. [CrossRef]

35. Mohammadkhani, A.; Stoddard, F.L.; Marshal, D.R.; Uddin, M.N.; Zhao, X. Starch extraction and amylose analysis from half seeds. Starch-Stärke 1999, 51, 62-66. [CrossRef] 
36. Mahmood, T.; Turner, M.A.; Stoddard, F.L. Comparison of methods for colorimetric amylose determination in cereal grains. Starch-Stärke 2007, 59, 357-365. [CrossRef]

37. Konik-Rose, C.M.; Moss, R.; Rahman, S.; Appels, R.; Stoddard, F.; McMaster, G. Evaluation of the $40 \mathrm{mg}$ swelling test for measuring starch functionality. Starch-Stärke 2001, 53, 14-20. [CrossRef]

38. Konik, C.M.; Mikkelsen, L.M.; Moss, R.; Gore, P.J. Relationships between physical starch properties and yellow alkaline noodle quality. Starch-Stärke 1994, 46, 292-299. [CrossRef]

39. AACC. Method 76-21.02. General Pasting Method for Wheat or Rye Flour or Starch Using the Rapid Visco Analyser. In AACC Approved Methods of Analysis, 11th ed.; American Association of Cereal Chemists International: St. Paul, MN, USA, 1997.

40. Kariluoto, S.; Edelmann, M.; Nyström, L.; Sontag-Strohm, T.; Salovaara, H.; Kivelä, R.; Herranen, M.; Korhola, M.; Piironen, V. In situ enrichment of folate by microorganisms in beta-glucan rich oat and barley matrices. Int. J. Food Microbiol. 2014, 176, 38-48. [CrossRef]

41. Kariluoto, S.; Vahteristo, L.; Salovaara, H.; Katina, K.; Liukkonen, K.H.; Piironen, V. Effect of baking method and fermentation on folate content of rye and wheat breads. Cereal Chem. 2004, 81, 134-139. [CrossRef]

42. Kariluoto, M.S.; Vahteristo, L.T.; Piironen, I.V. Applicability of microbiological assay and affinity chromatographic purification followed by high performance liquid chromatography (HPLC) in studying folate contents in rye. J. Sci. Food Agric. 2001, 81, 938-942. [CrossRef]

43. Edelmann, M.; Kariluoto, S.; Nyström, L.; Piironen, V. Folate in oats and its milling fractions. Food Chem. 2012, $135,1938-1947$. [CrossRef] [PubMed]

44. Evers, T.; Millar, S. Cereal grain structure and development: Some implications for quality. J. Cereal Sci. 2002, 36, 261-284. [CrossRef]

45. Singh, N.; Singh, P.; Shevkani, K.; Virdi, A.S. Amaranth: Potential source for flour enrichment. In Flour and Breads and Their Fortification in Health and Disease Prevention, 2nd ed.; Preedy, V.R., Watson, R.R., Eds.; Academic Press: London, UK, 2019; Chapter 10; pp. 123-135. [CrossRef]

46. Pospišil, A.; Pospišil, P.; Varga, B.; Svečnjak, Z. Grain yield and protein concentration of two amaranth species (Amaranthus spp.) as influenced by the nitrogen fertilization. Eur. J. Agron. 2006, 25, 250-253. [CrossRef]

47. Joshi, D.C.; Sood, S.; Hosahatti, R.; Kant, L.; Pattanayak, A.; Kumar, A.; Yadav, D.; Stetter, M.G. From zero to hero: The past, present and future of grain amaranth breeding. Theor. Appl. Genet. 2018, 131, 1807-1823. [CrossRef]

48. Hricová, A.; Kečkešová, M.; Gálová, Z.; Libiaková, G.; Gajdošová, A. Investigation of protein profile changes in amaranth seeds after radiation mutagenesis. Chem. Listy 2011, 105, 542-545.

49. Bojórquez-Velázquez, E.; Velarde-Salcedo, A.J.; León-Rodríguez, A.D.; Jimenez-Islas, H.; Pérez-Torres, J.; Herrera-Estrella, A.; Espitia-Rangel, E.; de la Rosa, A.P.B. Morphological, proximal composition, and bioactive compounds characterization of wild and cultivated amaranth (Amaranthus spp.) species. J. Cereal Sci. 2018, 83, 222-228. [CrossRef]

50. Praznik, W.; Mundigler, W.; Kogler, A.; Pelzl, B.; Huber, A.; Wollendorfer, M. Molecular background of technological properties of selected starches. Starch-Stärke 1999, 51, 197-211. [CrossRef]

51. Williams, J.T.; Brenner, D. Grain amaranth (Amaranthus species). In Underutilized Crops: Cereals and Pseudocereals, 1st ed.; Williams, J.T., Ed.; Chapman \& Hall: London, UK, 1995; pp. 129-187.

52. Kong, X.; Bao, J.; Corke, H. Physical properties of Amaranthus starch. Food Chem. 2009, 113, 371-376. [CrossRef]

53. Hoover, R.; Sinnott, A.W.; Perera, C. Physicochemical characterization of starches from Amaranthus cruentus grains. Starch-Stärke 1998, 50, 456-463. [CrossRef]

54. Choi, H.; Kim, W.; Shin, M. Properties of korean amaranth starch compared to waxy millet and waxy sorghum starches. Starch-Stärke 2004, 56, 469-477. [CrossRef]

55. Chandla, N.K.; Saxena, D.C.; Singh, S. Physico-chemical, pasting and morphological characterization of grain amaranth starch Asian J. Chem. 2016, 28, 2457-2460. [CrossRef]

56. Condés, M.C.; Añón, M.C.; Dufresne, A.; Mauri, A.N. Composite and nanocomposite films based on amaranth biopolymers. Food Hydrocoll. 2018, 74, 159-167. [CrossRef]

57. Yuan, T.Z.; Liu, S.; Reimer, M.; Isaak, C.; Ai, Y. Evaluation of pasting and gelling properties of commercial flours under high heating temperatures using Rapid Visco Analyzer 4800. Food Chem. 2021, 344, 128616. [CrossRef]

58. Macrone, M.F. Starch properties of Amaranthus pumilus (seabeach amaranth): A threatened plant species with potential benefits for the breeding/amelioration of present Amaranthus cultivars. Food Chem. 2001, 73, 61-66.

59. Baker, L.A.; Rayas-Duarte, P. Freeze-thaw stability of amaranth starchand the effects of salt and sugars. Cereal Chem. 1998, 75, 301-307. [CrossRef]

60. Lindeboom, N.; Chang, P.R.; Tyler, R.T. Analytical, biochemical and physicochemical aspects of starch granule size, with emphasis on small granule starches: A review. Starch-Stärke 2004, 56, 89-99. [CrossRef]

61. Chandla, N.K.; Saxena, D.C.; Singh, S. Processing and evaluation of heat moisture treated (HMT) amaranth starch noodles; An inclusive comparison with corn starch noodles. J. Cereal Sci. 2017, 75, 306-313. [CrossRef]

62. Wang, C.X.; Zhu, C.C.; Lu, C.Y.; Yang, Y.; Li, Q.F.; Liu, Q.Q.; Zhang, C.Q. Grain quality and starch physicochemical properties of chalky rice mutant. Agronomy 2021, 11, 1575. [CrossRef]

63. Li, W.; Cao, F.; Fan, J.; Ouyang, S.; Luo, Q.; Zheng, J.; Zhang, G. Physically modified common buckwheat starch and their physicochemical and structural properties. Food Hydrocoll. 2014, 40, 237-244. [CrossRef] 
64. Siwatch, M.; Yadav, R.B.; Yadav, B.S. Chemical, physicochemical, pasting and microstructural properties of amaranth (Amaranthus hypochondriacus) flou as affected by different processing treatments. Qual. Assur. Saf. Crop. 2019, 11, 3-13. [CrossRef]

65. Perez-Rea, D.; Antezana-Gomez, R. The Functionality of pseudocereal starches. In Starch in Food, 2nd ed.; Sjöö, M., Nilsson, L., Eds.; Woodhead Publishing: Cambridge, UK, 2018; Chapter 12; pp. 509-542. [CrossRef]

66. Kang, I.J.; Byun, M.W.; Yook, H.S.; Bae, C.H.; Lee, H.S.; Kwon, J.H.; Chung, C.K. Production of modified starches by gamma irra-diation. Radiat. Phys. Chem. 1999, 54, 425-430. [CrossRef]

67. Bao, J.S.; Ao, Z.H.; Jane, J.L. Characterisation of physical properties of flour and starch obtained from gamma-irradiated with rice. Starch-Stärke 2005, 57, 480-487. [CrossRef]

68. Kong, V.; Kasapis, S.; Bao, J.; Corke, H. Effect of gamma irradiation on the thermal and rheological properties of grain amaranth starch. Radiat. Phys. Chem. 2009, 78, 954-960. [CrossRef]

69. Kong, X.; Kasapis, S.; Bao, J. Viscoelastic properties of starches and flours from two novel rice mutants induced by gamma irradiation. LWT-Food Sci. Technol. 2015, 60, 578-582. [CrossRef]

70. Soriano-García, M.; Arias-Olguín, I.I.; Montes, J.P.C.; Ramírez, D.G.R.; Figueroa, J.S.M.; Flores-Valverde, E.; Valladares-Rodríguez, M.R. Nutritional functional value and therapeutic utilization of Amaranth. J. Anal. Pharm. Res. 2018, 7, 596-600. [CrossRef]

71. Gujska, E.; Kuncewicz, A. Determination of folate in some sereal and commercial cereal-grain products consumed in Poland using trienzyme extraction and high performance liquid chromatography methods. Eur. Food Res. Technol. 2005, 221, 208-213. [CrossRef]

72. Hager, A.S.; Wolter, A.; Jacob, F.; Zannini, E.; Arendt, E.K. Nutritional properties and ultra-structure of commercial gluten free flours from different botanical sources compared to wheat flours. J. Cereal Sci. 2012, 56, 239-247. [CrossRef]

73. Motta, C.; Delgado, I.; Matos, A.S.; Gonzales, G.B.; Torres, D.; Santos, M.; Chandra-Hioe, M.V.; Arcot, J.; Castanheira, I. Folates in quinoa (Chenopodium quinoa), amaranth (Amaranthus sp.) and buckwheat (Fagopyrum esculentum): Influence of cooking and malting. J. Food Compos. Anal. 2017, 64, 181-187. [CrossRef] 